\title{
The potential effects of climate change on the status of Seychelles frogs (Anura: Sooglossidae)
}

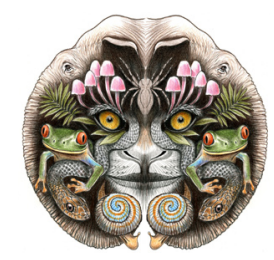

\author{
Justin Gerlach \\ Nature Protection Trust of Seychelles, 133 Cherry Hinton Road, Cambridge CB1 7BX, UK \\ Email: jstgerlach@aol.com
}

Date of publication (online): 26 November 2011 Date of publication (print): 26 November 2011 ISSN 0974-7907 (online) | 0974-7893 (print)

Editor: Paul Pearce-Kelly

Editor's Note: The author uses a very low temperature increase scenario relative to the global average increase trajectory we are currently proceeding on. He doesn't take other climate change related impacts into consideration, such as extreme weather events, which would further compound the threat factors. Although this paper can be considered to portray a relatively conservative impact evaluation, it shows how even relatively modest changes can impact these species, and therefore, is a valuable contribution to the literature and associated discussion.

\section{Manuscript details:}

Ms \# o2619

Received 30 October 2010

Final received 19 June 2011

Finally accepted 06 October 2011

Citation: Gerlach, J. (2011). The potentia effects of climate change on the status of Seychelles frogs (Anura: Sooglossidae). Journal of Threatened Taxa 3(11): 2153-2166.

Copyright: (c) Justin Gerlach 2011. Creative Commons Attribution 3.0Unported License. JoTT allows unrestricted use of this article in any medium for non-profit purposes, reproduction and distribution by providing adequate credit to the authors and the source of publication.

Author Details: Justin GeRLACH is the Scientific Coordinator for the Nature Protection Trust of Seychelles. His research focus is on the evolution of island ecosystems and their responses to anthropogenic change.

Acknowledgements: This work was supported by the Mohamed bin Zayed Species Conservation Fund (project 0925406).
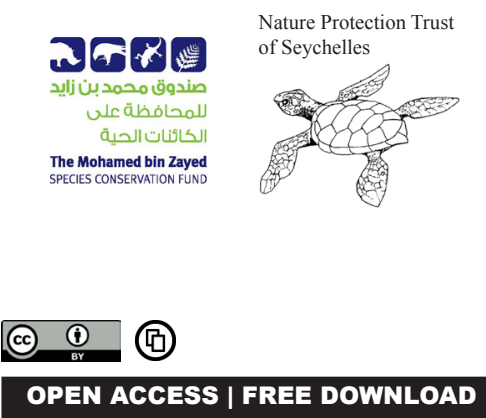

Abstract: The status of the Seychelles frogs of the family Sooglossidae was investigated, using monitoring data from 1993-2010, climate data from 1998-2010 and studies of populations and local climate effects. Climate monitoring at each plot covered rainfall and temperature, with leaf wetness and soil moisture being monitored additionally at one site. Analysis of the data and ecological modelling of the distribution identify geographical patterns in climate which explain the present distribution of the different sooglossid species. In addition it identifies a drying trend in the first quarter of the year which corresponds to frog population declines in mid-altitude forests. This is interpreted as evidence of an ongoing deterioration in the suitability of habitats for the frogs, with declines recorded in areas of marginal suitability. By extension it is assumed that currently optimal frog habitat is also undergoing a decline in suitability, due to early year decreases in moisture. Projected changes in climate were used to predict changes in ranges of the sooglossids over the next 90 years. This predicts significant declines, with the possible extinction of the palm frog Sooglossus pipilodryas by 2100 . Accordingly all four sooglossid species should be categorised as Endangered, rather than their current status of Vulnerable. Captive assurance colonies have not been successfully established to date. Captive groups have been maintained with a high degree of success but breeding has not been recorded so far. Further work needed for the conservation of the frogs is outlined: development of a reliable method of monitoring the cryptic $S$. thomasseti and development of captive breeding techniques.

Keywords: Climate change, populations, Seychelles, Sooglossidae, Sooglossus.

\section{INTRODUCTION}

Dramatic declines in many species of amphibians have been reported in recent years. These have been attributed to general threat factors such as habitat loss and invasive species (Baille et al. 2004; Vié et al. 2009) but particular concern has been raised over the impacts of diseases and climate change, to which some amphibians are particularly vulnerable (Baillie et al. 2004; Stuart et al. 2004, 2008; Thomas et al. 2004; Foden et al. 2008; Stork 2009).

The main effects of climate change relevant to amphibians are expected to include general global increases in temperature (although with local decreases), changes in rainfall patterns, raised sea levels and increases in storm intensity and the frequency of climatic extremes. Amphibians are often expected to be particularly vulnerable to climate change due to their dependence on water and humid microhabitats. In addition many species show a high degree of geographical restriction, further increasing their vulnerability to extinction. The frog family Sooglossidae is extremely vulnerable in this regard. This family is restricted to the Seychelles islands and has a total range of $50 \mathrm{~km}^{2}$, with species ranges varying between 15 and $50 \mathrm{~km}^{2}$.

Seychelles supports an important amphibian fauna in the world, despite being small in terms of species it is dominated by endemic species 
(12 out of 13) and contains six endemic genera and one endemic family (the Sooglossidae). Six of these species are listed as threatened on the IUCN Red List, these include all four members of the Sooglossidae which are currently categorised as Vulnerable on the basis of restricted range. The impacts of climate change have not been considered fully in Red List assessments for the Seychelles amphibians. Recent data suggests that the threat from climate change may be severe for at least some species of the Sooglossidae. The Sooglossidae occur in forests of higher elevation and are associated with damp habitats. At least one of the species, Sooglossus thomasseti, is considered to be associated with mist-forest habitat and would therefore be expected to be particularly vulnerable to climate change.

The Seychelles islands have an equatorial climate with relatively little variation, sea-level temperatures range from $24-31{ }^{\circ} \mathrm{C}$. In addition, many of the islands are high (over $10 \mathrm{~m}$ high, rising to $991 \mathrm{~m}$ ), minimising the potential impacts of climate change on these islands. Despite this there is evidence of significant climate change impacts, including recent species extinctions (Gerlach 2010). These extinctions have been attributed to climatic stresses and ecosystem changes resulting from changing rainfall patterns and sea level rise. Changes in rainfall may have particularly severe effects on species naturally at the edge of climate tolerance (such as the snail Rhachistia aldabrae on the semi-arid atoll of Aldabra: Gerlach 2007b) and those adapted to high rainfall systems (such as cloud forest species, including the snail Pachnodus velutinus: Gerlach 2010). The Sooglossidae are all associated with high altitude habitats, and at least two species (S. sechellensis and S. thomasseti) are believed to be limited to high rainfall and cloud forest habitats (Nussbaum 1984; Gerlach 2007a). The results of a study into climate limitations and impacts of climate change on the Sooglossidae are reported here.

\section{METHODS}

\section{Study species}

The Sooglossidae comprise four species in two genera; Sooglossus (comprising S. thomasseti (Image 1) and $S$. sechellensis (Image 2)) and a second genus for which two names have been proposed almost simultaneously: Seychellophryne (Nussbaum \& Wu 2007) and Leptosooglossus (van der Meijden et al. 2007). This latter genus comprises two species, $S$. gardineri (Image $3 \mathrm{a}, \mathrm{b}$ ) and S. pipilodryas (Image 4)). Due to the uncertainty of nomenclatural precedence in this case, all Sooglossidae are here referred to the genus Sooglossus for convenience. In addition to the four Seychelles species the monotypic Indian family Nasikabatrachidae has been placed in the Sooglossidae on cladistic grounds (Frost et al. 2006). This wider usage of Sooglossidae lacks major synapomorphies, obscures 65 million years of evolution and combines ecologically, behaviourally and morphologically different taxa, accordingly it is not followed here, and the conventional usage of Sooglossidae as a family of frogs endemic to the Seychelles islands is retained. Sooglossus sensu stricto are small to medium size frogs found at high altitudes (typically above $400 \mathrm{~m}$ above sea level (asl)) in leaf litter or in rock crevices. Both species have terrestrial eggs and carry their tadpoles on the female's back (Brauer 1898; Gerlach 2007a). Seychellophryne/Leptosooglossus species may be found down to $200 \mathrm{~m}$ asl and may be terrestrial or partially arboreal. S. gardineri has terrestrial eggs with direct development, the reproductive mode of $S$. pipilodryas is unknown. All four species are currently categorised as Vulnerable on the basis of their restricted ranges and the ongoing habitat deterioration caused by invasive plant species (Gerlach 2007a).

\section{Study site}

The study concentrated on the island of Silhouette. This is the second highest $(774 \mathrm{~m})$ and third largest (1995ha) of the Seychelles Islands. As such, it supports examples of most of the habitats of the islands (Senterre et al. 2009) and all of the amphibians. This makes it suitable for comparison of the effects of different ecological factors on the different species. A total of 500 locations on the island were searched for sooglossids. Individual locations were at least $25 \mathrm{~m}$ apart and covered an area of $50 \mathrm{~m}^{2}$.

Distribution surveys were also carried out on Mahé to provide a test of the ecological modelling of distribution derived from the more detailed Silhouette studies.

\section{Sooglossid surveys}

Populations were estimated using manual 


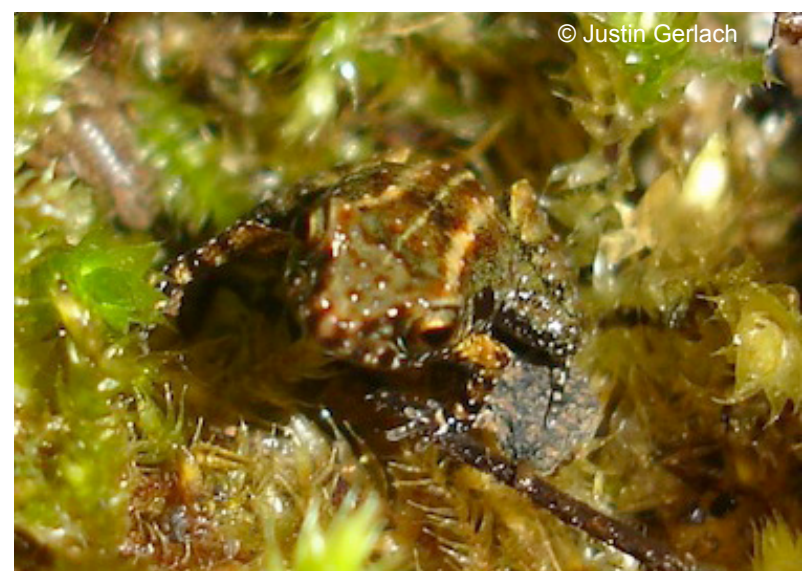

Image 1. Sooglossus thomasseti Mahe

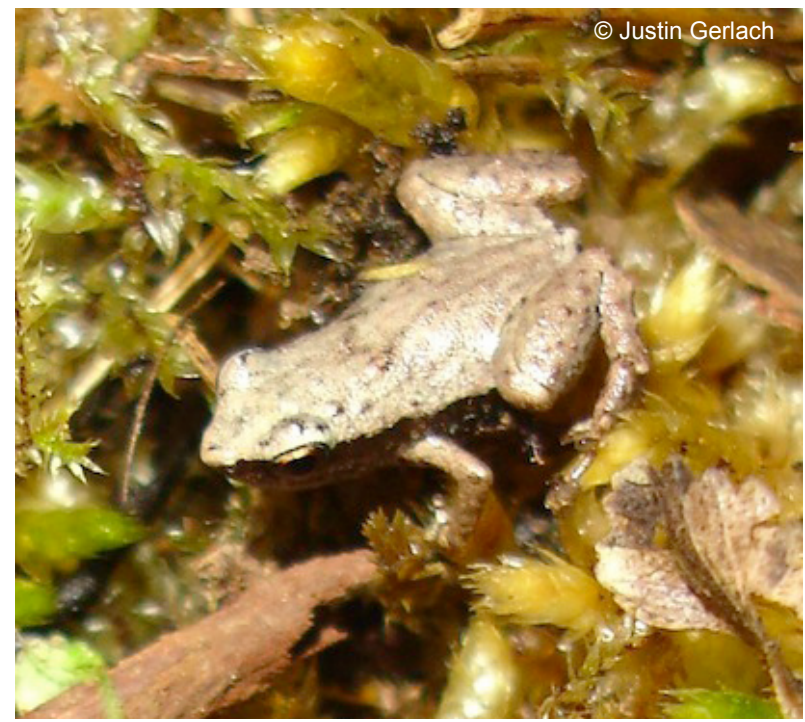

Image 3a. Sooglossus gardineri Mahe

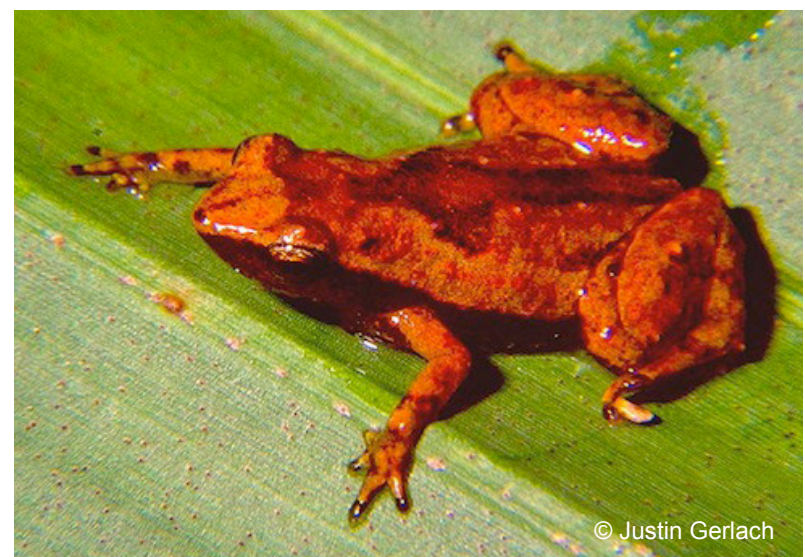

Image 4. Sooglossus pipilodryas Silhouette

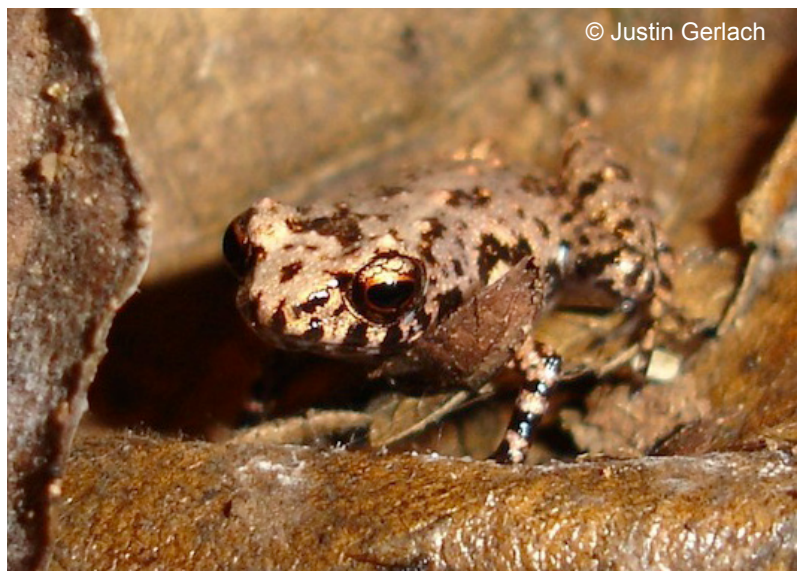

Image 2. Sooglossus sechellensis Mahe

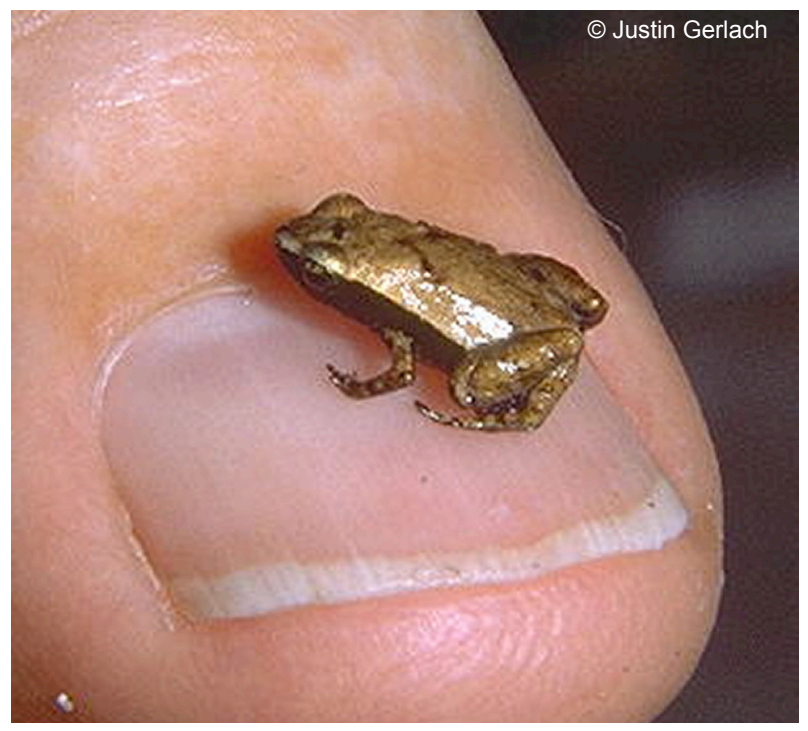

Image 3b. Sooglossus gardineri Silhouette on finger

searching of quadrats. $1 \times 1 \mathrm{~m}$ sample areas were used in all habitats occupied by the sooglossids. Leaf litter was removed from a $10 \mathrm{~cm}$ band around the quadrat perimeter, and then each leaf was removed, starting from one corner. This systematic approach ensured that no frogs were overlooked or escaped from the quadrat before being detected. Twenty quadrats were used at each site. This method only sampled leaf-litter species and was supplemented by searches of trees. Arboreal sooglossids have only been located in the leaf axils of palms and bananas, and at each site 20 palms of each species (Nephrosperma vanhouetteana, Pheonicophorium borsigianum, Verschaffeltia splendida and Roscheria melanochaetes) and all bananas (5-20 individuals) were searched. Each interstice was examined by carefully pulling down 
the leaf rachis. Quadrats provide a direct estimate of population density; for palm axils the number of frogs per palm could be converted to a density estimate by combination with quantified habitat data.

Monitoring surveys were carried out in wet and dry seasons from 1994 in two sites, and a third from 2000. Since 2009 these have been combined with vegetation and invertebrate diversity monitoring and climate recording. Monitoring continued until April 2011.

\section{Habitat}

Habitat (vegetation and invertebrates) were studied in 1990 and 2000, and monitored biannually from 2009. Habitat was evaluated in 30 sites, including 20 occupied by sooglossid frogs. In each site $105 \times 5$ m quadrats were used to record all trees over $2 \mathrm{~m}$ tall and an equal number of $1 \mathrm{~m}^{2}$ quadrats to record all herbaceous and shrubby plants (angiosperms and pteridophytes) under $2 \mathrm{~m}$. All were recorded as individuals and identified to species. In addition to vegetation recording invertebrates were studied by using ten $1 \mathrm{~m}^{2}$ quadrats in the same sites. In each quadrat leaves were turned over and the number of ants, earwigs and woodlice were recorded as indicators of common sooglossid prey items. These were not identified to species due to difficulties of field identification for these taxa. The effects of habitat components on frog abundance have been reported previously (Gerlach 2007).

Forest health monitoring was established in 2009, recording leaf cover and size, and the abundance of restricted species, especially cloud forest indicators (the Vulnerable tree species Glionnetia sericea and the microhabitat fern Haplopteris ensiformis) and the Critically Endangered Trilepisium gynandrum (mid-altitude tree) and the fern Thelypteris puberula (proposed Critically Endangered).

\section{Climate}

Three aspects of climate were investigated:

(i) Temporal monitoring from a fixed site - allowing changes in rainfall and temperature to be evaluated over a 12 year period. Daily data were collected from 1998-2010, comprising $0700 \mathrm{hr}$ temperatures (to $\left.0.1^{\circ} \mathrm{C}\right)$ and daily rainfall $(0.5 \mathrm{~mm})$.

(ii) Geographical variation-enabling frog distribution to be related to local climate. Data were collected from two sites in 2008-2010 and six sites from $2009-2010$. These comprised temperature $\left(0.1^{\circ} \mathrm{C}\right)$ every two hours and rainfall in $0.2 \mathrm{~mm}$ increments. Comparisons were made with monthly total rainfall, $0700 \mathrm{hr}$ temperatures and the number of days where temperature exceeded the maximum active sooglossid temperature $\left(28^{\circ} \mathrm{C}\right)$. Microclimates were investigated by recording temperature in shaded sites within boulder fields and in non-boulder field sites $10 \mathrm{~m}$ away to determine whether localised frog distributions could be explained by microclimate effects.

(iii) Relationship between rainfall, surface moisture and soil moisture - two species (S. sechellensis and $S$. thomasseti) are most abundant in cloud forests. These may be more affected by cloud moisture than direct rainfall. Data were collected in 2009, comprising recording every two hours of temperature $\left(0.1^{\circ} \mathrm{C}\right)$, soil moisture (proportion of water per unit of soil) and leaf wetness (percentage), and rainfall in $0.2 \mathrm{~mm}$ increments.

\section{Ecological modelling}

Distribution models of the four species were created for Silhouette Island, enabling prediction of distribution changes in the future. These models used the distribution data from the surveys -155 sites and 10 selected environmental variables covering altitude, climate (maximum annual temperature, quarterly rainfall), slope, rock cover, tree cover and vegetation components previously identified as having

Table 1. Significant correlates of frog diversity (from Gerlach 2007a).

\begin{tabular}{|l|l|l|l|}
\hline & Environment & Plants & Animals \\
\hline Sooglossus sechellensis & altitude & Colea sechellensis & Mollusca \\
\hline Sooglossus thomasseti & & Glionnetia sericea, palms & Amphipoda, Hirudinea \\
\hline Sooglossus gardineri & & & Amphipoda, Hirudinea, Lepidoptera \\
\hline Sooglossus pipilodryas & & Palms & Chelicerata, Hymenoptera (ants) \\
\hline
\end{tabular}


a significant correlation with sooglossid distributions

- Colea sechellensis, Glionnetia sericea, palms; Table

1). As ecological niche models can vary depending on the method of construction, two different methods were used: the genetic algorithm for rule-set prediction (GARP) (Stockwell \& Noble 1992; Pereira 2002), and the maximum entropy approach (Maxent) (Phillips et al. 2006).

The models were refined by successively removing ecological variables and repeating the model generation. Testing the reliability of distribution models is complicated by the lack of independence between the data used to generate the model and the available data for testing. In the present study the models were generated from data from Silhouette Island and were tested by comparison with distribution records from Mahé.

\section{Projected future distributions}

The ecological distribution modelling was repeated using projected temperature and rainfall projections over the next 90 years to predict likely future range changes by 2100 . Projected temperature change was at least $1.3^{\circ} \mathrm{C}$ over the next 90 years (based on regional estimate ranges of $0.14-0.37{ }^{0} \mathrm{C}$ per decade [Christensen et al. 2007; Cai et al. 2011], and existing Seychelles data giving a trend of $0.25^{\circ} \mathrm{C}$ per decade trend [Gerlach 2010]) and rainfall change to $82-100 \%$ of 1998 levels (Christensen et al. 2007).

\section{RESULTS}

\section{Sooglossid surveys}

The distribution of sooglossids on Silhouette Island is shown in Images $5 \& 6$. This confirms the distributions reported in earlier studies with the addition of data on population densities. Results of repeated surveys at Gratte Fesse, Jardin Marron and Mon Plaisir are summarised in Fig. 1. Distribution of high density areas along two transects are shown in Fig. 2 .

\section{Climate preferences}

All four sooglossid species are restricted to cool, damp areas with none found in areas regularly experiencing temperatures over $28^{\circ} \mathrm{C}$ (Table 2). The most extreme limitations are found in $S$. thomasseti

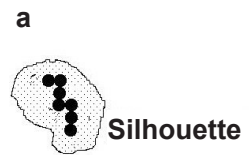

C Silhouette
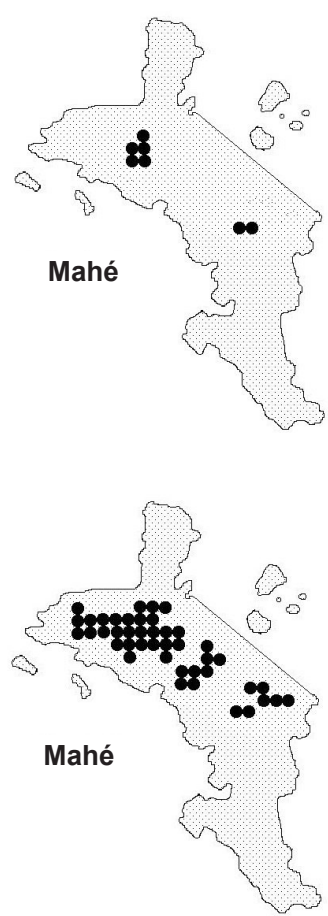

b

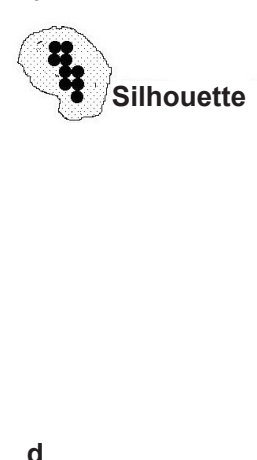

Silhouette

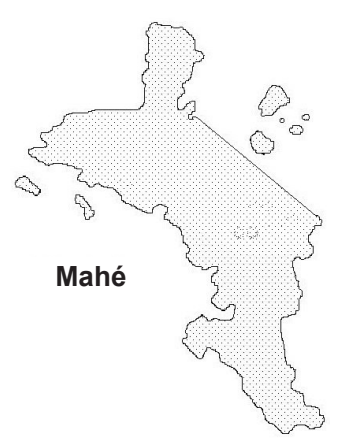

Image 5. Recorded distribution of sooglossids on Mahé and Silhouette islands, Seychelles. a - Sooglossus thomasseti; b - S. sechellensis; c - S. gardineri; d - S. pipilodryas 

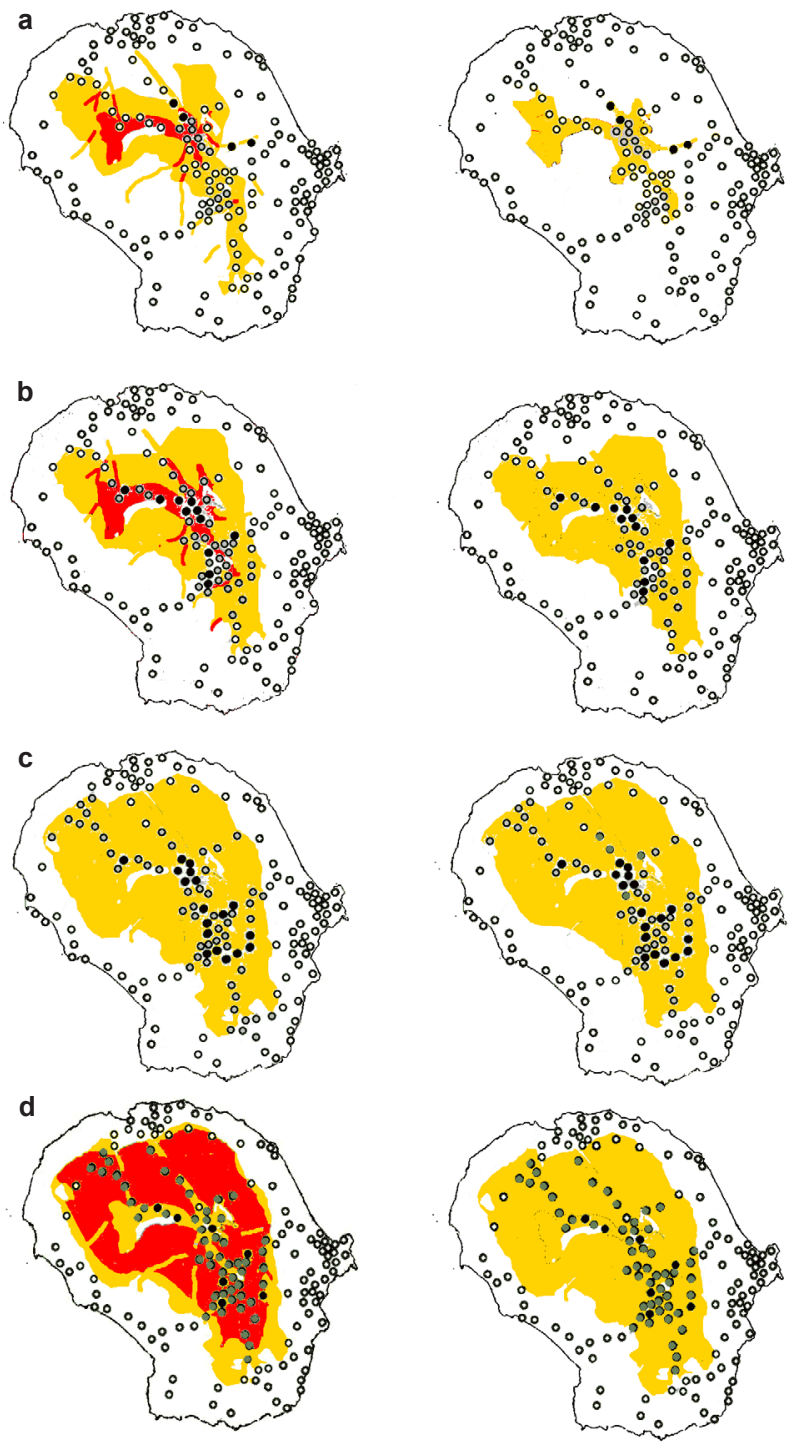

Image 6. Modelled and recorded distribution of sooglossids on Silhouette Island. GARP modelled distribution shown on left, Maxent on right. Probability of occurrence shown in colours: orange $-\mathbf{5 0}-75 \%$, red $>75 \%$. Black circle sooglossid observed, grey circle - sooglossid heard but not observed, open circle - absent.

a - Sooglossus thomasseti; b - S. sechellensis; c - S. gardineri; d - S. pipilodryas

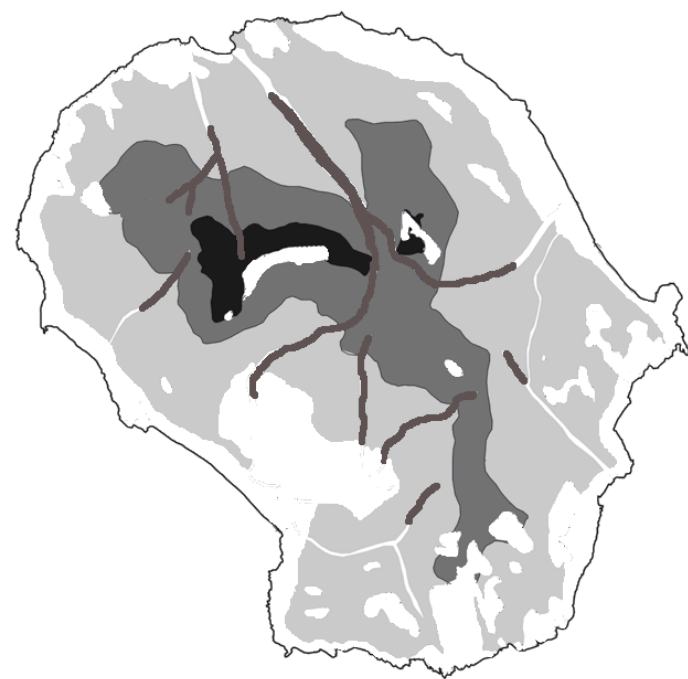

Image 7. Habitats on Silhouette Island, after Senterre et al. 2008 excluding areas unsuitable for sooglossids (non woodland areas and coconut plantations). Pale grey - low to mid-altitude forest (low suitability), dark grey - high forest (suitable), dark grey lines - boulder fields (high suitability), black - cloud forest (high suitability)

and $S$. sechellensis which are mainly restricted to areas with high levels of cloud cover.

\section{Habitat}

Ranges of sooglossids overlap several different habitat types (Image 7). Previously reported (Gerlach 2007) correlations between habitat factors and frog abundance are listed in Table 1.

\section{Climate}

\section{Temporal monitoring}

No clear long term (10 year) patterns were identified in data from La Passe; there were negative trends in both average temperatures and rainfall but these were not significant in regression analysis $\left(\mathrm{P}>0.05, \mathrm{R}^{2}<\right.$ 0.12 in both cases). Significant changes were detected, however, for rainfall in the first quarter of the year (an annual decrease of $-48.053 \mathrm{~mm}, \mathrm{P}<0.01, \mathrm{R}^{2}=0.539$ ), in other quarters the trend was increasing rainfall, but

Table 2. Altitude and climate ranges for the four species in the family Sooglossidae

\begin{tabular}{|l|c|c|c|c|c|c|}
\hline & \multicolumn{2}{|c|}{ Temperature $\left({ }^{\circ} \mathbf{C}\right)$} & Humidity $(\%)$ & \multicolumn{3}{c|}{ Altitude range $(\mathbf{m})$} \\
\hline & Normal range & maximum & minimum & main & valleys & total \\
\hline Sooglossus thomasseti & $18-25$ & 27 & 85 & $>400$ & $>310$ & $150-991$ \\
\hline Sooglossus sechellensis & $18-26$ & 30 & 85 & $>300$ & $>220$ & $300-991$ \\
\hline Sooglossus gardineri & $18-28$ & 31 & 85 & $>95$ & $>40$ & $150-991$ \\
\hline Sooglossus pipilodryas & $18-28$ & 31 & 85 & $>95$ & $>40$ & $150-550$ \\
\hline
\end{tabular}



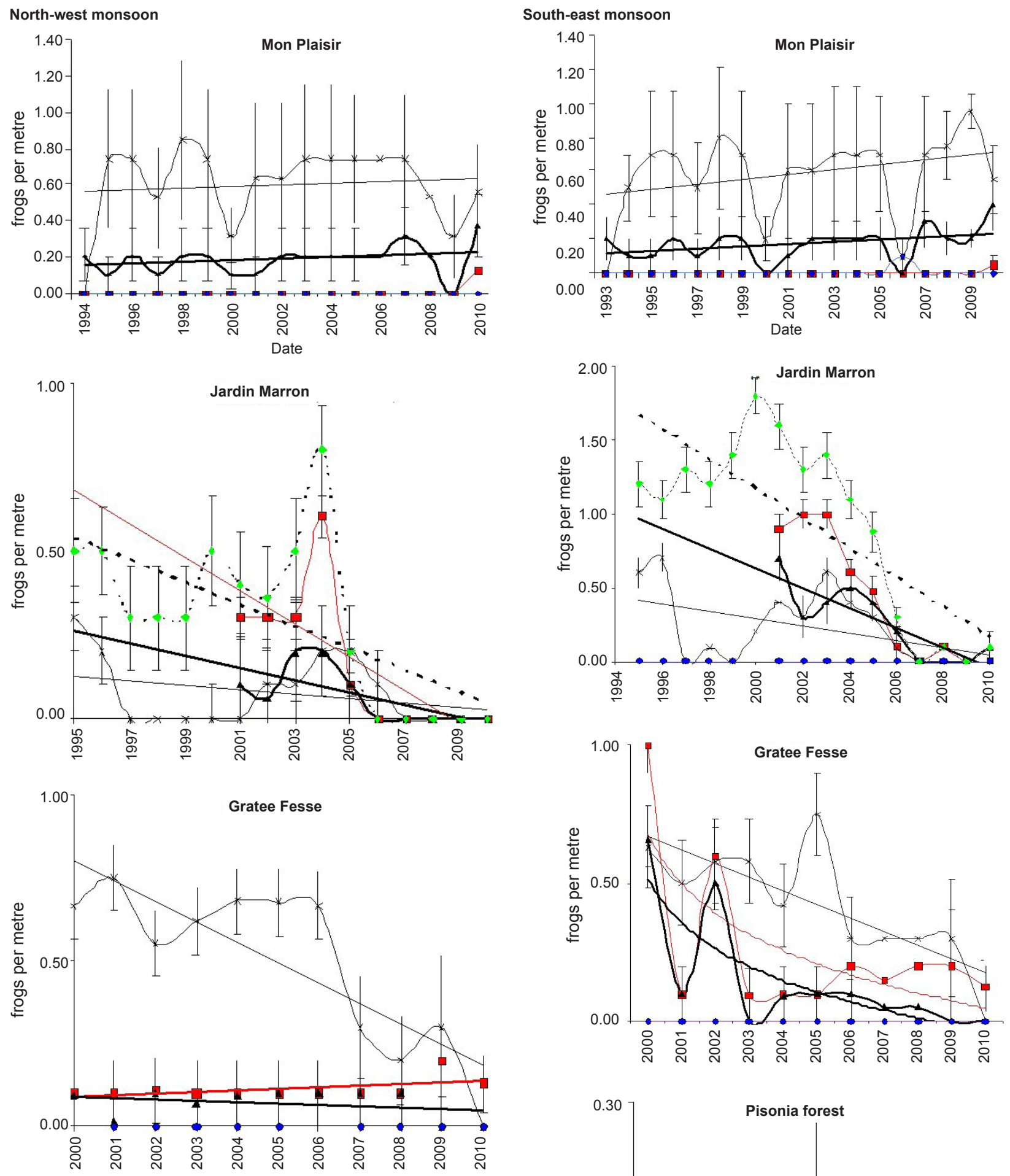

- pipilodryas

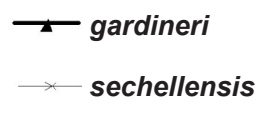

- thomasseti

- pipilodryas + gardineri

Figure 1. Population density data, showing changes in recorded frog population densities at Mon Plaisir (550m), Jardin Marron $(390 \mathrm{~m})$, Gratte Fesse $(350 \mathrm{~m})$ and the Pisonia forest $(500 \mathrm{~m})$.

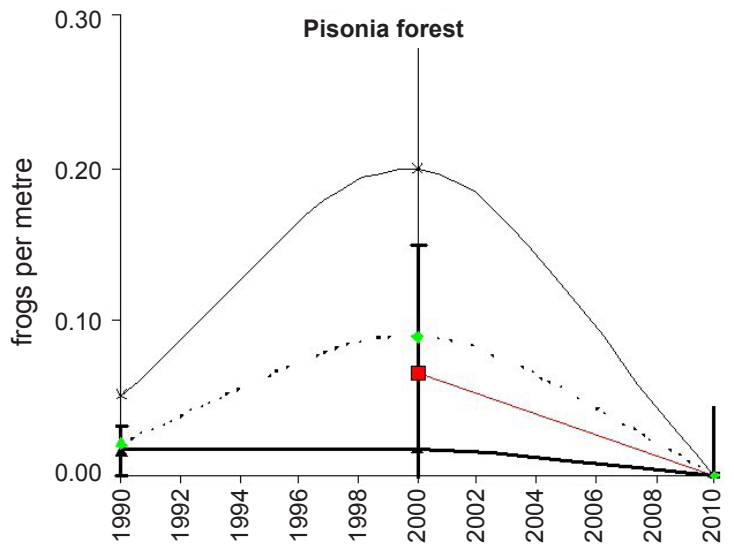


Mt. Corgat

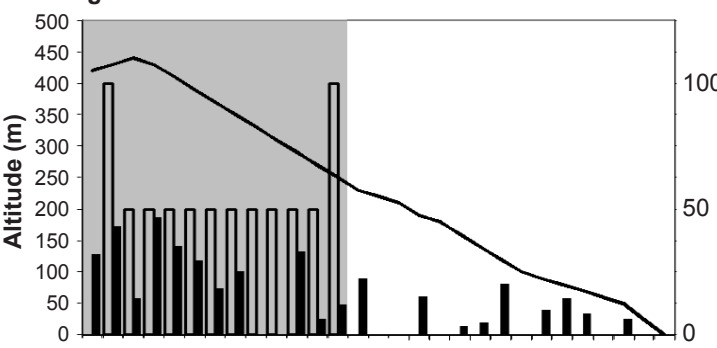

Gratte Fesse

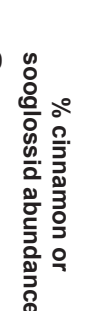

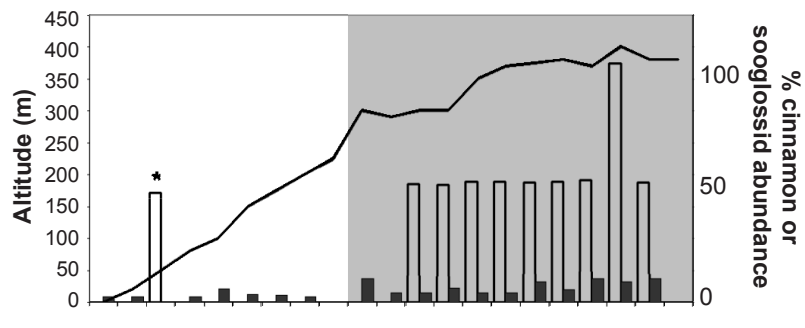

Figure 2. Sooglossid populations, climate and levels of invasion by Cinnamomum verum along transects to Mont Corgat and Gratte Fesse. White bars - sooglossid density recorded as 0 (absent), 50 (low density - heard but not quantifiable), 100 (moderate to high - recorded in quadrats). Black bars - percentage of Cinnamomum trees. Shading - climatically suitable areas are shaded. A boulder field site with an exceptionally low altitude population of sooglossids is marked with an asterisk on the Gratte Fesse transect, this has a suitable microclimate in a generally unsuitable zone.
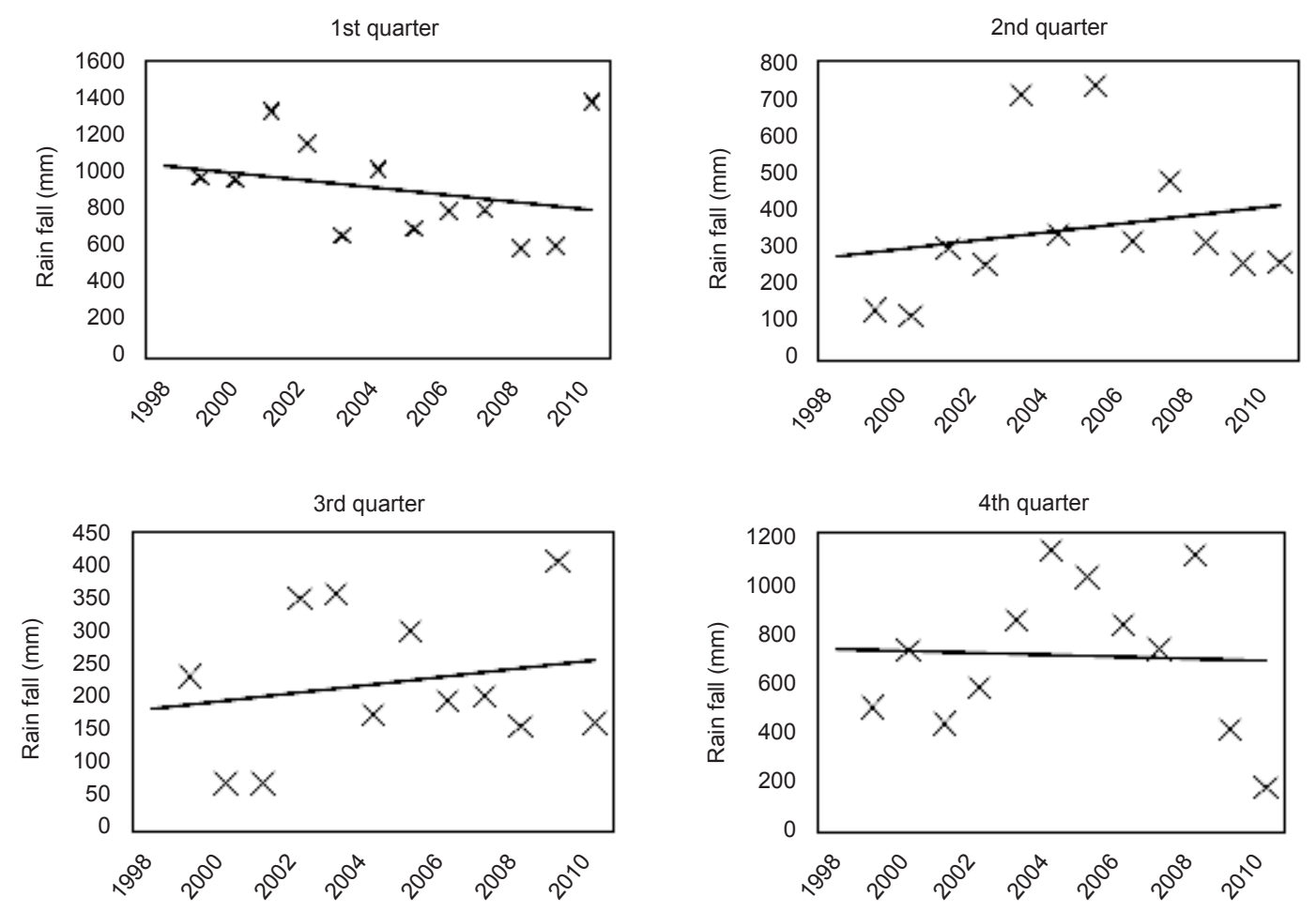

Figure 3. Quarterly rainfall changes at La Passe in $\mathrm{mm}$

this was not significant $\left(\mathrm{P}>0.05, \mathrm{R}^{2}<0.097\right)$ (Fig. 3). 7 am temperatures also showed some seasonal variation: temperatures decreased in all seasons $\left(0.02^{\circ} \mathrm{C}\right.$ per year, $\left.\mathrm{R}^{2}=0.07\right)$ except for doldrums of April-May which increased by $0.03^{\circ} \mathrm{C}\left(\mathrm{R}^{2}=0.11\right)$. The months with the strongest increases were May $\left(0.05^{\circ} \mathrm{C}\right.$, $\left.\mathrm{R}^{2}=0.177\right)$, June $\left(0.09^{\circ} \mathrm{C}, \mathrm{R}^{2}=0.256\right)$, and August $\left(0.048^{\circ} \mathrm{C}, \mathrm{R}^{2}=0.145\right)$. The only month with strong cooling was December $\left(0.04^{\circ} \mathrm{C}, \mathrm{R}^{2}=0.106\right)$ although this was principally due to two low temperature years (2003 and 2009), exclusion of these results in a nonsignificant cooling of $0.01^{\circ} \mathrm{C}\left(\mathrm{R}^{2}=0.05\right)$.

\section{Geographical variation Temperature}

Altitude effects were found for temperature with an overall $0.84^{\circ} \mathrm{C}$ decrease in temperature per $100 \mathrm{~m}$. The east of the island was hotter than the west, with up to $10 \%$ difference between eastern and western sites at comparable altitudes. This was most pronounced at high temperatures; when $0700 \mathrm{hr}$ temperatures approached $26^{\circ} \mathrm{C}$ on the east side temperature differences were negligible (1\%). This may be due to a cooling effect of the seasonal winds. The west has a lower altitude increment than the east, with a 
$0.3-0.5{ }^{\circ} \mathrm{C}$ per $100 \mathrm{~m}$ decrease, this is most pronounced in January-February, in association with the seasonal north-easterly winds causing a greater altitudinal cooling effect in the west. The east has $0.7-1.1{ }^{0} \mathrm{C}$ decrease per $100 \mathrm{~m}$, this cooling is most pronounced in May-August and in December, again in accordance with seasonal (May-September) south-easterly winds causing cooling on the east side.

\section{Rainfall}

Altitudinal variation was recorded for rainfall but this was not a straightforward pattern. Seasonal changes in distribution were identified with higher levels of rainfall in the east of the island December-February (north-west monsoon), higher rainfall at intermediate altitudes in March-May (doldrums), high rainfall in the north-west in June-August (south-east trades) and high levels at high altitude in September-November (doldrums). This corresponds to a pattern of higher rainfall at high altitudes combined with a rain-shadow effect driven by seasonal wind patterns.

\section{Microclimates}

The main surveys and the climate monitoring consider air temperature. In the study of microhabitats ground temperature was found to be $1-5 \%$ lower than the air temperature (recorded $1.5 \mathrm{~m}$ above the ground). Boulder fields were found to be $2-6 \%$ lower than the air temperature (Fig. 4).

\section{Relationship between rainfall and moisture}

Leaf wetness and soil moisture were recorded in only one site (Mon Plaisir). No significant correlations were found between these factors and rainfall. Leaf wetness varied from 7.7-100\%. During rain wetness was constantly above $28 \%$, but near saturation levels (approaching 100\%) were recorded in the absence of rain at the time of recording or in the previous three hours. This suggests that rainfall is not the primary cause of leaf wetness at this site. Average daily leaf wetness was stable between 2200-0800 hrs, but declined after $0800 \mathrm{hrs}$, reaching a minimum at 1200 1300 , correlating closely with air temperature. There is a seasonal component to this circadian pattern: in July the decrease is $80-95 \%$ to $50 \%$, thereafter the nighttime wetness is close to $100 \%$ and the minimum is less pronounced, in November-December the minimum is $70-75 \%$. From these data it can be concluded that

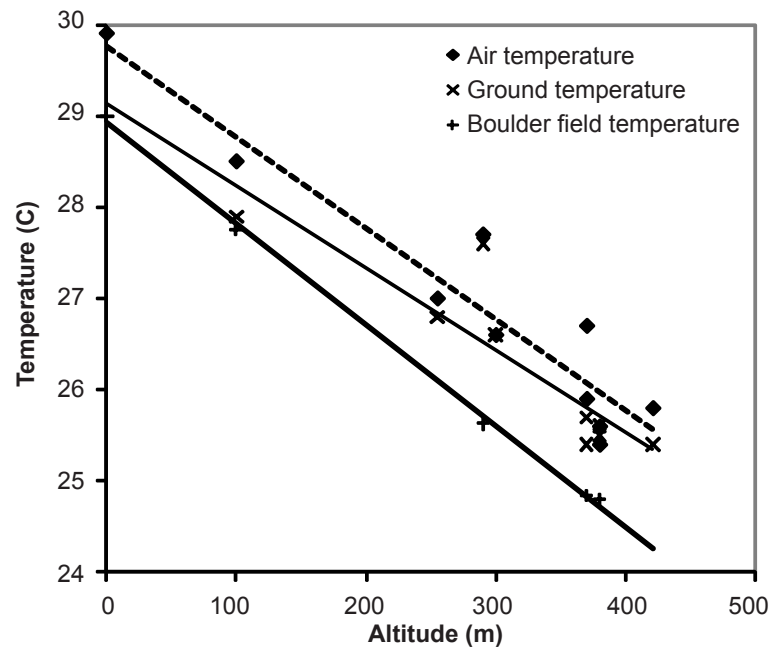

Figure 4. Microclimate effects on temperature - air, ground and boulder field temperatures

leaf wetness in the cloud forest is caused primarily by cloud condensation, which is strongly influenced by temperature, giving rise to a strong circadian and much weaker seasonal pattern.

Soil moisture did not correlate with rainfall or with leaf wetness. No temporal patterns were identified other than the greatest rate of drying being in JulySeptember (values less than -0.027), and the lowest rate in December $(-0.018--0.012)$. Fluctuations were relatively small, less than $10 \%$ per hour. Almost all data points gave negative values, showing that the soil was freely draining and that all moisture entering the soil (from rain or cloud condensation) was rapidly lost. Positive values (indicating increasing soil moisture) were recorded as only isolated events lasting 1-84 hours. These corresponded to days with prolonged rain, rather than isolated rain records, and were recorded in otherwise dry months (July, August, October).

Rainfall was strongly seasonal at all altitudes with high rainfall in December-April. Most rainfall was recorded at night (2000-0200 hr) and rainfall was very rare at 1100-1500 hr, although there was no clear pattern during the day. Rainfall was mostly isolated to short showers, lasting less than an hour; low numbers of hours of rain were recorded in most months except December (210 hours in July, but 86-140 in August-November) which had 178 hours of rain. In comparison, hours with detectable moisture (from rain or cloud, as indicated by a leaf wetness value of over $50 \%$ ) increased from July through to December 
(from 536 to 726), with a temporary drop to 673 in November.

\section{Comparison of sooglossid population changes with climatic factors}

Rainfall decreased significantly in the first quarter $\left(-48.053 \mathrm{~mm} / \mathrm{yr}, \mathrm{P}<0.01, \mathrm{R}^{2}=0.539\right)$ due to strong reduction in amount and duration of rainfall in February (and to a lesser extent in March). This is balanced by weak increases in other quarters $\left(\mathrm{P}>0.05, \mathrm{R}^{2}<\right.$ 0.097) resulting in stable annual totals. The number of wet days in April increased, giving a more uniform distribution of rain outside of the first quarter. The only marked change outside of the first quarter was a highly significant increase in the number of wet days and rainfall in July; this was countered by decreases in wet days in other months.

No significant changes in air temperature were detected $\left(\mathrm{P}>0.05, \mathrm{R}^{2}<0.12\right)$. The months with the strongest $7 \mathrm{am}$ temperatures increases were May $\left(0.05^{\circ} \mathrm{C}, \mathrm{R}^{2}=0.177\right)$, June $\left(0.09^{\circ} \mathrm{C}, \mathrm{R}^{2}=0.256\right)$ and August $\left(0.048^{\circ} \mathrm{C}, \mathrm{R}^{2}=0.145\right)$, all non-significant $(\mathrm{P}$ $>0.05)$. The only month with strong cooling was December $\left(0.04^{0} \mathrm{C}, \mathrm{R}^{2}=0.106, \mathrm{P}>0.05\right)$ although this was principally due to two low temperature years (2003 and 2009), exclusion of these results in a nonsignificant cooling of $0.01^{\circ} \mathrm{C}\left(\mathrm{R}^{2}=0.05, \mathrm{P}>0.05\right)$. No significant correlations were found between frog population and temperature changes.

Frog population monitoring data covers three sites studied semi-annually (Mon Plaisir, Jardin Marron and Gratte Fesse) and one site studied on three occasions (Pisonia forest). Although the latter site covers 20 years the data is too limited to identify any patterns. At high altitude (Mon Plaisir, 550m) no significant population changes were detected in any species or season, population densities were not significantly different in different seasons. At Jardin Marron (390 m) population densities in the north-west monsoon were 2-3 times higher than in the southeast. High population densities were recorded in the north-west monsoon season in 1992-2002, followed by strong declines; by 2007 densities were very low. This corresponds to high first quarter rainfall years in 1999-2002 at La Passe, first quarter rainfall appears to be a good predictor of population levels. In the southeast season population densities remained stable until 2004, as with the north-west monsoon low levels were reached in 2007. At Gratte-Fesse $(360 \mathrm{~m})$ population densities were higher in the north-west monsoon than in the south-east, but only for S. pipilodryas and $S$. gardineri and only strongly so before 2003. The north-west monsoon saw population decreases from 2007 onwards, this was initially rapid (2006-2007) for $S$. sechellensis. For $S$. gardineri populations have been low and stable, S. pipilodryas low and stable or increasing. In the south-east season declines started earlier, in 2003 (with the exception of 2005 which was a high density year with high first quarter rainfall). For S. pipilodryas and S. gardineri populations fluctuated until 2003, from 2004 populations dropped to low levels in both species. For $S$. pipilodryas there were slight increases, and slight decreases for $S$. gardineri. In every case declines were most pronounced for the commonest species at that site. These results indicate that population density declines correspond to decreases in first quarter rainfall, and are most pronounced in the north-west monsoon (the first quarter of the year). Declines in the south-east season also correspond to changes in first quarter rainfall although no significant changes in the corresponding quarter $\left(3^{\text {rd }}\right)$ were identified. High altitude sites (over $390 \mathrm{~m}$ ) are buffered from these changes. The Gratte Fesse site shows a slightly different pattern to that of Jardin Marron, with a delayed population decline, high population levels and a higher density of $S$. sechellensis. Climate data for 2009 show that Gratte Fesse has 14\% more rain than Jardin Marron delaying the point at which declines occur.

The only statistically significant correlations between frog populations and climatic factors were for $1^{\text {st }}$ quarter rainfall. S. gardineri and S. pipilodryas populations combined correlate with $1^{\text {st }}$ quarter rainfall at Jardin Marron $\left(\mathrm{R}^{2}=0.4842\right)$, but not otherwise. This correlation is largely due to the significant correlation for $S$. gardineri $\left(\mathrm{R}^{2}=0.527\right)$, a weaker correlation was found for $S$. pipilodryas $\left(\mathrm{R}^{2}=0.4009\right)$. S. sechellensis correlated with rainfall at Gratte Fesse $\left(\mathrm{R}^{2}=0.3563\right)$. These statistical results support the patterns described above: S. sechellensis is restricted to extremely damp sites and is found at high altitudes, which are relatively stable climatically. Lower altitude sites are probably of marginal suitability for this species due to climatic instability and they are strongly affected by decreases in rainfall (as at Gratte Fesse). S. gardineri and $S$. pipilodryas are more tolerant of dry conditions, only 
at Jardin Marron were conditions sufficiently marginal for the rainfall correlation to be apparent. Thus local population declines reflect the vulnerability of sites to the effects of reduced rainfall in the wet season.

\section{Population compared to habitat change}

No significant change in vegetation composition was recorded over the study period in the range of the sooglossids.

\section{Distribution modelling}

The predicted and recorded distribution of sooglossids are shown in Images $6 \& 8$. In all cases GARP and Maxent models produced similar results, with the Maxent models giving a wider predicted distribution. The comparison with the Mahé distribution data (Image 8) gives a close match between predicted and observed distributions, indicating that both models types are reliable. The components of the most accurate models for each species are listed in Table 3.

\section{Projected impacts of climate change}

Projected future distributions as a result of climate change are summarised in Table 4 and Fig. 5, with the probable extinction of sooglossids on Silhouette island by 2100 and high levels of fragmentation of the Mahé populations.

\section{DISCUSSION AND CONCLUSIONS}

The present study has confirmed earlier suggestions (Nussbaum 1984; Gerlach 2007a) that climate is the primary determinant of the distribution of the Sooglossidae. There is evidence of population declines at lower altitudes in sites that are close to the limits of climatic suitability.

Changes in temperature, rainfall and cloud cover may be expected as a result of global climate change. There are no reliable models for the Seychelles islands as the geographical area is too small for reliable modelling at present. Long-term temperature monitoring data is available for sea level at Mahé island and indicate a rise of at $0.25^{\circ} \mathrm{C}$ per decade (Gerlach 2010). Higher altitude data is too limited for meaningful evaluation but with an altitude range of $991 \mathrm{~m}$ it is probable that a similar pattern of
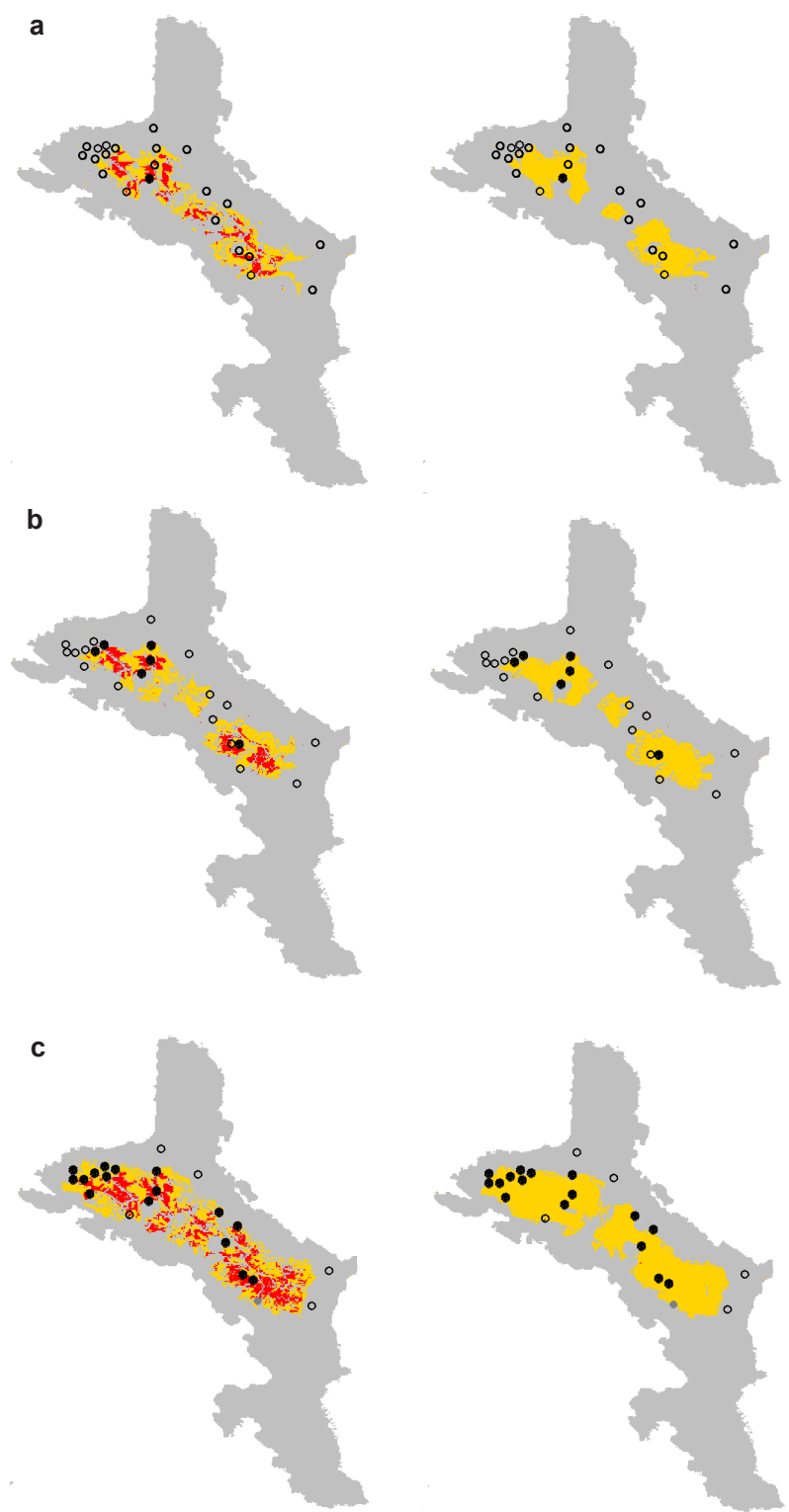

Image 8. Modelled and recorded distribution of Sooglossidae on Mahé Island. Key as Image 2. a - Sooglossus thomasseti; b - S. sechellensis; c - S. gardineri

Table 3. Components of the most accurate distribution models for sooglossids.

\begin{tabular}{|l|l|}
\hline Species & Components \\
\hline S. sechellensis & rain, temperature, tree cover, Colea \\
\hline S. thomasseti & Rain, temperature, rock, tree cover, palms \\
\hline S. gardineri & Rain, temperature, tree cover \\
\hline S. pipilodryas & Rain, temperature, tree cover, palms \\
\hline
\end{tabular}

temperature rise will extend over all sites. Rainfall data shows an increased frequency of both low and high rainfall periods over a long time series for Mahé 
Table 4. Projected changes in Sooglossidae distribution (area of occupancy in $\mathrm{km}^{2}$ ) as a result of climate changes

\begin{tabular}{|l|c|c|c|c|c|c|}
\hline GARP & $\begin{array}{c}\text { Present } \\
\text { range (2010) }\end{array}$ & $\mathbf{2 0 3 0}$ & $\mathbf{2 0 5 0}$ & $\mathbf{2 0 7 0}$ & $\mathbf{2 0 9 0}$ & $\mathbf{2 1 0 0}$ \\
\hline Sooglossus thomasseti & 15 & 13 & 12 & 10 & 8 & 5 \\
\hline Sooglossus sechellensis & 25 & 20 & 18 & 15 & 12 & 10 \\
\hline Sooglossus gardineri & 50 & 40 & 30 & 25 & 20 & 20 \\
\hline Sooglossus pipilodryas & 15 & 12 & 6 & 2 & 1 & 0 \\
\hline Maxent & & & & & & \\
\hline Sooglossus thomasseti & 16 & 14 & 13 & 11 & 8 & 6 \\
\hline Sooglossus sechellensis & 27 & 22 & 19 & 17 & 14 & 11 \\
\hline Sooglossus gardineri & 53 & 43 & 33 & 26 & 22 & 20 \\
\hline Sooglossus pipilodryas & 15 & 13 & 7 & 3 & 1 & 0 \\
\hline
\end{tabular}

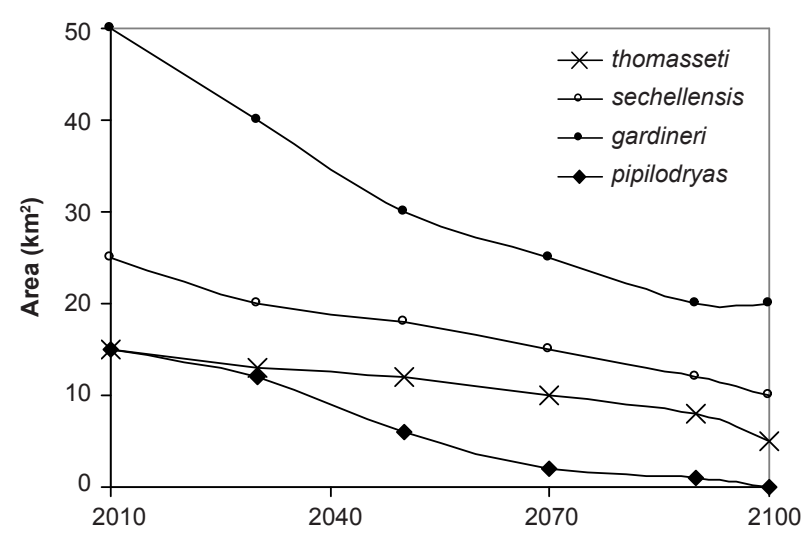

Figure 5. Projected changes in Sooglossidae distribution (in $\mathbf{k m}^{2}$ ) as a result of climate changes

island. The present study also recorded changes in rainfall patterns (although annual totals for Silhouette island remain stable). These recorded changes suggest that conditions at lower altitude sites will become progressively more stressful for sooglossids. At present there is no evidence of significant change in the high altitude sites which support the main sooglossid populations. In March 2009 all habitats on Silhouette island (including previously stable mist forest) were found to be dry; sooglossids were restricted to small depressions in the forest floor. This restriction had not been observed previously (observations starting in mid-1997). These exceptional dry conditions were repeated in March-June 2010 and from March 2011 onwards. Long-term survival in these conditions may be unlikely.

The projected climate change is predicted to lead to sooglossid range contractions of at least $60 \%$ by 2100 (Figs 5; Table 4). This may lead to the extinction of sooglossids on Silhouette island by 2100, at which point the Silhouette endemic S. pipilodryas would be extinct. Over this period the Mahé populations are expected to become significantly fragmented. At present, roads and areas of un-forested habitat (rock, tea plantations, scrub and gardens) probably prevent significant gene flow between the northern, central and southern areas; by 2030 these will probably form completely isolated populations. Palaeoclimatological records suggest that the temperatures projected from 2100 were exceeded on several occasions in the past million years (approximately 130,000 and 325,000 years ago) (Petite et al. 1999; Jouzel et al. 2007). At these times similar range contractions are likely to have occurred, however, the present isolation of sooglossids on the islands of Mahé and Silhouette is thought to have arisen approximately 100,000 years ago when rising sea-levels separated the islands (Gerlach et al. submitted). Past fragmentation of the Mahé populations may be reflected in patterns of genetic diversity which would be worthy of further study.

All four sooglossid species are currently listed on the IUCN Red List as Vulnerable on the basis of their restricted ranges (Stuart et al. 2008). In the light of these recent changes and projections for future climate change all four sooglossids should be considered Endangered (criterion B2a,bii,iii) on the basis of restricted range (IUCN criteria for this category require an area of occupancy under $500 \mathrm{~km}^{2}$ ), fragmented range and declining area of occupancy and quality of habitat. Conservation of these species requires increased efforts to prevent significant future climate change and mitigation of current levels of change. Along 
with effective carbon dioxide emissions reductions, the only practical mitigation is restoration of degraded habitats (control of invasive plants) to maximise natural ecosystem adaptability. Establishment of assurance colonies may be needed to ensure the long term survival of these species. Long-term monitoring is also required, with the development of new methods more applicable to monitoring $S$. thomasseti.

\section{REFERENCES}

Baillie, J.E.M., C. Hilton-Taylor \& S.N. Stuart (eds). (2004). 2004 IUCN Red List of Threatened Species ${ }^{\mathrm{TM}}$. A Global Species Assessment. IUCN, Gland, Switzerland and Cambridge, UK, xxiv+191pp.

Brauer, A. (1898). Ein neuer Fall von Brutege bei Fröschen. Zoologische Jahrbücher Abtheilungen Systematik, Ökologie und Geograpie der Tiere 12: 89-94.

Cai, W., A. Sullivan, T. Cowan, J. Ribbe \& G. Shi (2011). Simulation of the Indian Ocean Dipole: A relevant criterion for selecting models for climate projections. Geophysics Research Letters 38: L03704

Christensen, J.H., B. Hewitson, A. Busuioc, A. Chen, X. Gao, I. Held, R. Jones, R.K. Kolli, W.-T. Kwon, R. Laprise, V. Magaña Rueda, L. Mearns, C.G. Menéndez, J. Räisänen, A. Rinke, A. Sarr \& P. Whetton (2007). Regional Climate Projections, pp. 847-940. In: Solomon, S., D. Qin, M. Manning, Z. Chen, M. Marquis, K.B. Averyt, M. Tignor \& H.L. Miller (eds.) Climate Change 2007: The Physical Science Basis. Contribution of Working Group I to the Fourth Assessment Report of the Intergovernmental Panel on Climate Change [Cambridge University Press, Cambridge, United Kingdom and New York, NY, USA.

Foden, W.B., G.M. Mace, J.-C. Vié, A. Angulo, S.M. Butchart, L. DeVantier, H.T. Dublin, A. Gutsche, S.N. Stuart \& E. Turak (2008). Species susceptibility to climate change impacts. Pp. 77-88. In: Vié, J.-C., C. Hilton-Taylor \& S.N. Stuart (eds). The 2008 Review of the IUCN Red List of Threatened Species. IUCN, Gland, Switzerland.

Frost, D.R., T. Grant, J. Faivovich, R.H. Bain, A. Haas, C.F.B. Haddad, R.O. De Sa, A. Channing, M. Wilkinson, S.C. Donnellan, C.J. Raxworthy, J.A. Campbell, B.L. Blotto, P. Moler, R.C. Drewes, R.A. Nussbaum, J.D. Lynch, D.M. Green \& W.C. Wheeler (2006). The amphibian tree of life. Bulletin of the American Museum of Natural History 297: 1-370.

Gerlach, J. (2007a). Distribution and status of the Seychelles frogs (Amphibia: Anura: Sooglossidae). Herpetological Journal 17: 115-122.

Gerlach, J. (2007b). Short-term climate change and the extinction of the snail Rhachistia aldabrae (Gastropoda:
Pulmonata). Biology Letters 3(5): 581-584.

Gerlach, J. (2010). Climate change, species extinctions and ecosystem collapse. Phelsuma 17A: 13-31.

Gerlach, J., Meijen A. van der, Boistel, R. (submitted). Interisland variation in sooglossids frogs. Amphibia-Reptilia

Jouzel, J., V. Masson-Delmotte, O. Cattani, G. Dreyfus, S. Falourd, G. Hoffmann, B. Minster, J. Nouet, J.M. Barnola, J. Chappellaz, H. Fischer, J.C. Gallet, S. Johnsen, M. Leuenberger, L. Loulergue, D. Luethi, H. Oerter, F. Parrenin, G. Raisbeck, D. Raynaud, A. Schilt, J. Schwander, E. Selmo, R. Souchez, R. Spahni, B. Stauffer, J.P. Steffensen, B. Stenni, T.F. Stocker, J.L. Tison, M. Werner \& E.W. Wolff (2007). Orbital and millennial Antarctic climate variability over the past 800,000 years. Science 317: 793-796.

Meijden, A. van der, R. Boistel, J. Gerlach, A. Ohler, M. Vences \& A. Meyer (2007). Molecular phylogenetic evidence for paraphyly of the genus Sooglossus, with the description of a new genus of Seychellean frogs. Biological Journal of the Linnean Society 91: 347-359

Nussbaum, R.A. (1984). Amphibians of the Seychelles, pp. 379-415. In: Stoddart, D.R. (ed.), Biogeography and Ecology of the Seychelles Islands. Dr. W. Junk Publishers, The Hague.

Nussbaum, R.A. \& S.-H. Wu (2007). Morphological assessments and phylogenetic relationships of the Seychellean frogs of the family Sooglossidae (Amphibia: Anura). Zoological Studies 46(3): 322-335.

Pereira, R.S. (2002). Desktop GARP. http://www.lifemapper. org/desktopgarp.

Petit, J.R., J. Jouzel, D. Raynaud, N.I. Barkov, J.M. Barnola, I. Basile, M. Bender, J. Chappellaz, J. Davis, G. Delaygue, M. Delmotte, V.M. Kotlyakov, M. Legrand, V.M., Lipenkov, C. Lorius, L. Pépin, C. Ritz, E. Saltzman \& M. Stievenard (1999). Climate and Atmospheric History of the past 420,000 years from the Vostok Ice Core, Antarctica. Nature 399: 429-436

Phillips, S.J., R.P. Anderson \& R.E. Schapire (2006). Maximum entropy modeling of species geographic distributions. Ecological Modeling 190: 231-259

Senterre, B., J. Gerlach, J. Mougal \& D. Matatiken (2009). Old growth mature forest types and their floristic composition along the altitudinal gradient on Silhouette Island (Seychelles) - the telescoping effect on a continental mid-oceanic island. Phytocoenologia 39: 157-174

Stockwell, D.R.B. \& I.R. Noble (1992). Induction of sets of rules from animal distribution data: a robust and informative method of analysis. Mathematics and Computers in Simulation 33: 385-390

Stork, N.E. (2009). Re-assessing current extinction rates. Biodiversity and Conservation 19: 357-371

Stuart, S.N., J.S. Chanson, N.A. Cox, B.E. Young, A.S.L. Rodrigues, D.L. Fischman \& R.W. Waller (2004). Status and trends of amphibian declines and extinctions 
worldwide. Science 306(5702): 1783-1786

Stuart, S.N., M. Hoffmann, J.S. Chanson, N.A. Cox, R.J. Berridge, P. Ramani \& B.E. Young (eds) (2008). Threatened Amphibians of The World. Lynx Edicions, Barcelone, 776pp.

Thomas, C.D., A. Cameron, R.E. Green, M. Bakkenes, L.J. Beaumont, Y.C. Collingham, B.F.N. Erasmus, M. Ferreira de Siqueira, A. Grainger, L. Hannah, L.
Hughes, B. Huntley, A. S. Van Jaarsveld, G.F. Midgley, L. Miles, M.A. Ortega-Huerta, A. Townsend Peterson, O.L. Phillips \& S.E. Williams (2004). Extinction risk from climate change. Nature 427: 145-148.

Vié, J.-C., C. Hilton-Taylor \& S.N. Stuart (eds.) (2009). Wildlife in a Changing World - An Analysis of the 2008 IUCN Red List of Threatened Species. Gland, Switzerland: IUCN, 180pp. 